Egi Putra, Adil Mubarak I Peran Pemerintah Daerah dalam Pencegahan Pencemaran Air Sungai Akibat Limbah Pabrik di Kecamatan Pancung Soal Kabupaten Pesisir Selatan

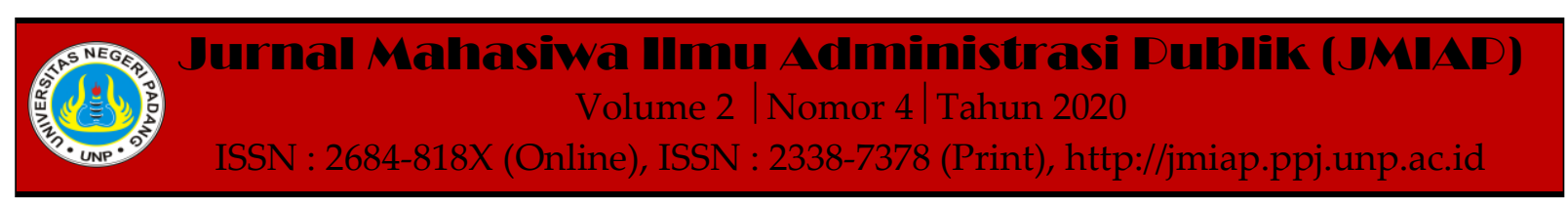

\title{
PERAN PEMERINTAH DAERAH DALAM PENCEGAHAN PENCEMARAN AIR SUNGAI AKIBAT LIMBAH PABRIK DI KECAMATAN PANCUNG SOAL KABUPATEN PESISIR SELATAN
}

\author{
Egi Putra $^{1(a)}$, Adil Mubarak ${ }^{2(b)}$ \\ ${ }^{1}$ Jurusan Ilmu Administrasi Negara, Universitas Negeri Padang \\ ${ }^{2}$ Jurusan Ilmu Administrasi Negara, Universitas Negeri Padang \\ a)egiputrayas@gmail.com, ${ }^{b}$ adilmubarak08@yahoo.co.id
}

\begin{abstract}
This study describes the role of the local government in this case the Environmental Service in river water pollution preventing due to factory waste in Pancung Soal District, Pesisir Selatan Regency. The Environment Agency carries out control, supervision and restoration to prevent river water pollution due to factory waste with various activities in every aspect. This research uses descriptive qualitative method. Informants were selected using a proportional sampling technique. Test the validity of the data using the observation persistence technique. The data was collected by means of interviews, observation and document analysis studies. The data analysis technique is done by means of data reduction, data presentation and drawing conclusions. The results of this study indicate the role of the Department of the Environment in preventing river water pollution has been carried out well and optimally even though there are many obstacles and problems in the field.
\end{abstract}

Keywords : Role, Local Government, River Water Pollution, Factory Waste

Corresponding author. Email.egiputrayas@gmail.com

How to cite this article. Putra, E \& Mubarak, A. (2020). Peran Pemerintah Daerah dalam Pencegahan Pencemaran Air Sungai Akibat Limbah Pabrik di Kecamatan Pancung Soal Kabupaten Pesisir Selatan. Jurnal Mahasiwa Ilmu Administrasi Publik (JMIAP) Jurusan Ilmu Administrasi Negara Fakultas Ilmu Sosial Universitas Negeri Padang, Volume 2 (4), Hal. 85-93.

http://jmiap.ppj.unp.ac.id

ISSN : 2684-818X (Online), ISSN : 2338-7378 (Print)

Copyright $\odot 2020$. Published by Labor Jurusan Ilmu Administrasi Negara FIS UNP, Padang 


\section{PENDAHULUAN}

Perkembangan perusahaan industri di dunia semakin tahun semakin meningkat termasuk di Indonesia. Salah satu perusahaan industri yang berkembang di Indonesia yaitu PT. Incasi Raya. Perusahaan PT. Incasi Raya berkiprah di bidang perkebunan dan pengolahan kelapa sawit, didirikan pada tahun 1996 yang berada di tiga kecamatan, Kecamatan Pancung Soal, Kecamatan Air Pura dan Kecamatan Lunang, Kabupaten Pesisir Selatan, Provinsi Sumatera Barat. Perusahaan semakin lama semakin berkembang dan hingga saat ini memiliki luas area perkebunan $12.247 \mathrm{Ha}$, dan mempunyai pabrik pengolahan kelapa sawit dengan kapasitas TBS 80 Ton/Jam.

Industri CPO Incasi Raya group memasuki bidang perkebunan dan pengolahan kelapa sawit sejak tahun 1984. Dari sebuah tradisi panjang kepiawaian masyarakat Sumatera Barat dan sekitarnya dalam bidang perdagangan dan perkebunan, awalnya Incasi Raya Grup tumbuh dan berdiri sebagai sebuah perusahaan kecil yang bergerak dalam hal pengolahan dan perdagangan kekayaan bumi. Dari sebuah usaha yang berskala kecil dalam bidang pengolahan dan perdagangan hasil bumi, grup ini telah menjelma menjadi sebuah grup yang berkiprah dalam bidang perkebunan, dan pabrik pengolahan.

Berdirinya perusahaan kelapa sawit PT. Incasi Raya di Nagari Inderapura, Kecamatan Pancung Soal diharapkan dapat menciptakan banyak peluang kerja bagi masyarakat setempat, sehingga sangat membantu perekonomian masyarakat yang sebelumnya yang hanya bekerja di ladang dan disawah, sekarang mereka sudah banyak bekerja di kebun kelapa sawit PT. Incasi Raya. Di samping itu pula masyarakat diharapkan menumbuhkan keinginan untuk menanamkan kelapa sawit, karena sudah ada perusahaan yang menampung untuk membeli.

Namun di satu sisi keberadaan PT. Incasi Raya dalam pengolahan kelapa sawit yang mana limbah dari hasil pengolahan yang sudah diolah terlebih dahulu dan kemudian dibuang ke sungai membuat sungai menjadi tercemar dan menganggu kehidupan ekosistem hewan yang hidup di dalam sungai tersebut, seperti lokan dan ikan menjadi berkurang, bahkan mati. Padahal lokan hidup di sungai itu adalah mata sumber pencaharian sebagian masyarakat sebelum PT. Incasi Raya membuka lahannya, lokan dan ikan lele merupakan hewan air tawar yang sangat banyak dicari oleh masyarakat karena lokan dan ikan lele mudah didapatkan. Pada tahun 2012 masyarakat nagari Inderapura Barat yang berprofesi sebagai pencari lokan pernah melaporkan pihak perusahaan PT. Incasi Raya atas dugaan pencemaran sungai di tempat mereka mencari lokan. Mereka mengatakan bahwasanya limbah yang sudah diolah yang dibuang ke sungai mengakibatkan pencemaran, banyaknya ditemukan spesies lokan yang mati dan juga kualitas air sungai menjadi menurunwarna sungai menjadi hitam kecoklat-coklatan dan berbau busuk.

Masyarakat nagari Inderapura Barat dan sekitarnya memanfaatkan sungai sebagai mata pencaharian yaitu menyelam lokan, yang mana dahulu sangat menopang perekonomian masyarakat. Lokan yang mereka dapatkan dijual ke luar kecamatan kabupaten hingga ke luar propinsi, seperti ke Painan, Padang, Bukittinggi dan hingga ke Bengkulu. Adapun penghasilan yang bisa mereka hasilkan setiap hari adalah dua ratus ribu hingga tiga ratus ribu atau setara dengan 2000 sampai 3000 butir lokan dalam sehari. Aktifitas lokan merupakan warisan turun temurun sejak dahulu.

Pada awalnya Perusahaan PT. Incasi Raya membuang limbah ke laut dengan menggunakan pipa berukuran \pm 12 inch, dan sekarang perusahaan membuang limbah ke parit-parit yang mengalir ke sungai. Dulu hal ini sudah dibahas dalam kesepakatan bersama berupa MOU masyarakat dengan pihak perusahaan yang mana dilarang membuang limbah ke aliran sungai. Dengan tercemarnya Sungai Muara Sakai dan Sungai Air Uba mengakibatkan 
penurunan drastis pada penghasilan masyarakat. Masyarakat kesulitan mendapatkan lokan-lokan, kalaupun ditemui hanya ditemui lokan-lokan mati dan ukurannya pun kecil. Akibatnya masyarakat berpindah-pindah lokasi dalam mencari lokan dan terkadang hanya dapat mengumpulkan 500 butir dalam satu hari dengan penghasilan sekitar 50 ribu/hari. Berdasarkan berita tentang pengaduan masyarakat ini disampaikan bahwasanya tim di lapangan menemukan fakta-fakta yang sesuai dengan pengaduan masyarakat.

Berdasarkan hasil wawancara dengan masyarakatyang bemamaAsri Jon sebagai salah seorang pencari lokan sejak tahun 1985 menuturkan bahwasanya sebelum lahan perkebunan dibuka terutama sebelum pabrik beroperasi lokan termasuk mudah dicari dan ukurannya pun besar-besar, dibanding dengan sekarang mencari lokan tidak semudah dulu lagi dan ukurannya pun agak kecil. Asri Jon juga mengatakan bahwasanya ia bersama kawan-kawannya yang berprofesi mencari lokan pernah melakukan unjuk rasa sebanyak dua kali. Begitu juga dengan pengakuan dari salah seorang tokoh masyarakat yang bernama Salfaruddin, yang mana beliau banyak mengetahui tentang dampak limbah ini, Salfaruddin mengatakan bahwasanya limbah dari hasil pengolahan kelapa sawit yang dibuang ke sungai lepas telah banyak berpengaruh terhadap tangkapan nelayan yang mencari lokan dan ikan lele.

Berdasarkan hasil wawancara penulis dengan Ibuk Yuliharce, ST. M.Si Kepala Bidang Pengelolaan Sampah Limbah B3 \& Pengendalian Pencemaran Lingkungan dapat disimpulkan sebagai berikut: Pertama, Pada umumnya sungai di Kabupaten Pesisir Selatan belum ada tercemar. Kedua, data sampel limbah dari PT. Incasi Raya ada sama kementerian dan belum diberikan ke dinas lingkungan hidup. Ketiga, seperti perusahaan lain PT. Incasin Raya sudah memiliki IPAL dan menggunakan teknologi aerop dan unaerop. Keempat, perusahaan melaporkan kepada dinas lingkungan hidup dalam per semester mengenai perkembangan dari pengolahan limbah.

Dinas Lingkungan Hidup sebagai perpanjangan dari pemerintah daerah diharapkan dapat mengupayakan berbagai bentuk usaha dalam mengatasi semua persoalan perusakan dan pencemaran lingkungan, terutam dalam hal menjaga kualitas melalui pengawasan dan perizinan yang berkala. Pada kenyaatannya tindakan tersebut tidak banyak memberikan dampak yang baik pada perbaikan kualitas air di sungai, bahkan yang terjadi adalah penurunan dari kualitas air tersebut.

Pemerintah Daerah memiliki kewajiban dalam melakukan pengendalian lingkungan hidup dan pengawasan agar mewujudkan daerah yang bebas dari pencemaran lingkungan dan perusakan. Perusahaan industri biasanya membuang limbah pada tengah malam ketika petugas maupun masyarakat tidak melakukan pengawasan terhadap perusahaan tersebut.

Adanya penurunan kualitas air akan mengakibatkan pencemaran terhadap lingkungan, yang akan berpengaruh juga pada keseimbangan kehidupan mahluk hidup yang ada pada lingkungan itu termasuk terhadap tingkat kesehatan masyarakat. Beberapa efek negatif yang diakibatkan oleh memburuknya kualitas lingkungan hidup adalah munculnya gangguan terhadap sistem alam seperti menyempitnya sungai dan menurunnya debit air, kurangnya nilai estetika, ancaman buruknya tingkat kesehatan termasuk kerugian yang muncul dari aspek ekonomi. Dalam Undang-Undang No 32 Tahun 2009 tentang perlindungan dan pengelolaan lingkungan hidup diatur mengenai asas-asas yang berkaitan dengan bagaimana melindungi dan mengelola lingkungan hidup. Selain itu UU PPLH jugamemberikan aturan yang jelas terkait hukuman yang akan didapatkan oleh pihakpihak yang terbukti terlibat dalam kegiatan perusakan dan pencemaran lingkungan.

Pada tingkat daerah, pengawasan dan pengendalian lingkungan hidup dilaksanakan oleh dinas lingkungan hidup. 
Sebagai salah satu instansi pelaksana otonomi daerah Dinas Lingkungan Hidup memiliki tupoksi dalam melaksanakan pengawasan dan pengendalian lingkungan, penanggulangan dampak lingkungan dan pemulihan dampak lingkungan. Tupoksi tersebut mempunyai arti penting dalam mewujudkan pembangunan daerah berwawasan lingkungan.

Berdasarkan permasalahan yang telah uraian di atas, peneliti tertarik membahas tentang "Peran Pemerintah Daerah dalam Pencegahan Pencemaran Air Sungai Akibat Limbah Pabrik".

\section{TINJAUAN PUSTAKA Peran Pemerintah Daerah}

(Mubarak, Ip, and Si n.d.) Adil (2014) menjelaskan bahwa pemerintah daerah sejatinya ada tiga fungsi utama harusnya dijalani dengan baik oleh Pemerintah baik dimanapun dan tingkat apapun, karena jika tigafungsi pokok tersebut bisa dijalani dengan baik maka dengan mudah beberapa permasalahan baik mengenai pembangunan maupun permasalahan sosial ekonomi masyarakat akan dapat diselesaikan. Tugas pokok tersebut ialah tugas pelayanan, tugas pemberdayaan dan tugas pembangunan. Namun pada kenyataannya masih terlihat bahwa pemerintah daerah belum sepenuhnya mampu membuat skala prioritas beserta strategi pencapaian dalam menjalankan fungsi pokok tersebut.

Dinas Lingkungan Hidup ialah perpanjangan urusan pemerintahan daerah yang megurusi bidang lingkungan hidup yang memiliki tugas melestarikan lingkungan hidup yang meliputi kegiatan penataan, pemanfaatan, pengembangan, pemulihan, pemeliharaan, pengawasan dan pengendalian lingkungan hidup. Selain itu Dinas Lingkungan Hidup juga memiliki tugas dan fungsi untuk melakukan pengawasan dan pencegahan. Dalam hal mengantisipasi adanya pencemaran ataupun perusakan lingkungan dilakukanlah penerbitan izin lingkungan yang merupakan salah satu syarat dalam mendapatkan izin usaha maupun izin kegiatan (Martika, 2017: 133)(Syaputri 2017).

Martika (2017: 134) menerangkan bahwa dengan adanya izin tersebut maka pengawasan dan pengendalian dapat dilakukan yang pada akhirnya akan membuat kesadaran pelaku usaha untuk ikut bertanggungjawab dalam menjaga kelestarian alam juga meningkat. Adapun jika dalam proses penerbitan izin lingkungan dan pengawasan pengelolaan lingkungan hidup, terdapat oknum pejabat yang tidak melakukannya sesuai aturan yang berlaku maka yang bersangkutan dapat ditindak secara pidana. Hal ini adalah usaha pencegahan terjadinya perusakan atau pencemaran lingkungan hidup yaitu dengan diterapkannya secara tegas penerbitan izin lingkungan, yang merupakan salah satu usaha penegakan hukum administrasi dalam upaya menerapkan pembangunan dan kegiatan yang ramah lingkungan.

Berdasarkan (Perda Pesisir Selatan 2014) Peraturan Daerah Kabupeten Pesisir Selatan No 5 Tahun 2014 Tentang Susunan Organisasi dan Tata Kerja Lembaga Teknis Pasal 24 ayat (1) bahwasanya Badan Lingkungan Hidup memiliki tugas melaksanakan perencanaan dan pembinaan serta pengendalian lingkungan hidup, dan dampak lingkungan hidup. Kemudian pada ayat (2) dijelaskan bahwasanya Dinas Lingkungan Hidup dalam melaksanakan tugas sebagaimana dimaksud pada ayat (1), menyelenggarakan fungsi:

a. Perumusan kebijakan teknis di bidang Lingkungan Hidup.

b. Pelayanan penunjang penyelenggaraan Pemerintahan Kabupaten di bidang Lingkungan Hidup.

c. Pemberian dukungan atas penyelenggaraan pemerintahan 
daerah di bidang Lingkungan Hidup, dan

d. Pelaksanaan tugas lain yang diberikan oleh pimpinan.

Dapat disimpulkan berdasarkan uraian diatas bahwasanya Pemerintah Daerah melalui Dinas Lingkungan Hidup mempunyai peran dalam pencegahan pencemaran yaitu perencanaan, pengendalian, pengawasan, pembinaan dan penegakan hukum.

\section{Pencegahan Pencemaran}

Menurut (Hendrawan 2010)Diana ( 2010: 17 ) pengendalian pencemaran ialah usaha yang dilakukan agar dapat memaksimalkan dampak yang baik dan meminimalkan dampak yang buruk. Hal ini sangat dipengaruhi oleh faktor politis, sosial dan budaya. Selanjutnya menurut Ginting ( dalam Diana, 2010: 17) dalam upaya pengendalian dan pencegahan lingkungan bisa dilakukan berbagai upaya, salah satu diantaranya seperti teknologi pencegahan dan penanggulangan, pendekatan institusional, pendekatan ekonomi dan pengelolaan lingkungan.

Teknologi pencegahan dan penanggulangan ialah sebuah mekanisme dalam merencanakan dan mengelola limbah yang dilakukan menggunakan beragam alat bantu. Dalam memilih teknologi yang akan digunakan, perlu diperhatikan beberapa hal berikut yaitu karakteristik limbah beserta kualitas standar effluent nya, dan bagimana rancang sistem dari alat yang dugunakan agar dapat merubah kualitas influent. Penanggulangan pencemaran yang diakibatkan oleh usaha industri ditekankan pada pemasangan peralatan pengolahan yang lebih dikenal dengan sebutan end pipe of treatment. Yang harus menjadi perhatian dalam pemasangan pengolah limbah ialah jenis zat pencemar, kepadatan limbah, durasinya berlangsung, jangkauan dan jumlah yang kena ( Diana, 2010: 17).
Selain hal di atas, cara lain yang juga dapat diaplikasikan dalam menanggulangi limbah adalah dengan melakukan proses recycle agar buangan tersebut menjadi sesuatu yang memiliki nilai ekonomis. Dengan mendaur ulang terdapat beberapa keuntungan yang akan diperoleh antara lain menurunkan biaya yang dikeluarkan untuk produksi, penghematan biaya dalam penganggulangan pencemaran limbah dan juga dapat memberikan pemasukan tambahan. Selain itu penanggulangan pencemaran dapat juga dengan upaya melakukan perubahan proses yang lebih baik sehingga zat pencemar yang terbuang lebih sedikit, menggantikan bahan baku yang berbahaya dan beracun dengan bahan lain yang lebih kecil resiko pencemarannya atau dengan bentuk teknologi tertentu yang mempunyai kadar buangan yang lebih rendah.

\section{Limbah Pabrik}

Berdasarkan (Indonesia 2001) Peraturan Pemerintah NO. 74 tahun 2001 tentang Pengelolaan Bahan Berbahaya dan Beracun, Pengelolaan ialah suatu upaya yang dapat menghasilkan, mengakut, mengedarkan, menyimpan, memanfaatkan dan membuang B3. Kemudian pengertian limbah dalam Peraturan ini ialah bahan yang karena sifatnya ataupun konsentrasinya maupun banyaknya, baik langsung maupun tidak langsung, kemudian bisa mencemari atau merusak lingkungan hidup, dan atau dapat membahayakan lingkungan hidup, kesehatan, serta kelangsungan hidup manusia dan makhluk lainnya. Sedangkan menurut Watts (1997), di dalam Mukhlishoh (2012) (dalam (Ichtiakhiri and Sudarmaji 2015)Tentrami Hayuning Ichtiakiri, dkk, 2015), limbah B3 diartikan semacam limbah padat atau kombinasi dari limbah padat, yang disebabkan karena jumlah, konsentrasinya, sifat fisik, kimia maupun yang bersifat infeksi yang mungkin tidak sampai dapat mengakibatkan meninggal dunia dan penyakit yang susah disembuhkan, yang 
mana substansinya bisa berakibat bagi kesehatan manusia atau lingkungan dikarenakan pengelolaan yang kurang tepat, baik itu penyimpanan, transport, ataupun dalam pembuangannya.

Berdasarkan (Peraturan Pemerintah Republik Indonesia 1999) Peraturan Pemerintah No. 18 tahun 1999 tentang Pengelolaan Limbah Bahan Berbahaya dan Beracun, limbah B3 dapat dikategorikan sesuai sumber dan karakteristiknya yakni limbah B3 dari sumber tidak spesifik, limbah B3 dari sumber yang spesifik dan limbah B3 dari bahan kimia yang kadaluarsa, tumpahan, bekas kemasan, dan buangan produk yang belum memenuhi spesifikasi.

\section{METODE PENELITIAN}

Berdasarkan permasalahan yang telah penulis kemukakan penelitian ini menggunakan metode penelitian kualitatif. Beberapa ahli memberikan pendapatnya tentang pengertian penelitian kualitatif ini. Pertama, Bogdan dan Taylor (dalam (Moleong 2006) Moleong, 2006: 4) metode kualitatif ialah metode penelitian yang berbentuk kata-kata tertulis ataupun lisan dari pelaku yang bisa diamati. Menurut dua ahli tersebut, metode ini diarahkan pada latar dan individu tersebut secara utuh. Kemudian ahli yang lain juga mendefinisikan terkait dengan pendekatan kualitatif ini. Williams (dalam Moleong, 2006: 5) menjelaskan bahwa penelitian kualitatif ialah kegiatan pengumpulan data pada suatu latar alamiah, kemudian dilaksanakan oleh peneliti yang memiliki ketertarikan secara alamiah. Adapun dalam penelitian ini, yang menjadi informan adalah sebagai berikut: (1)Kepala Bidang Pengelolan Sampah Limbah B3 \& Pengendalian Pencemaran Lingkungan Dinas Lingkungan Hidup Kabupaten Pesisir Selatan, (2)Wali Nagari Tluk Ampalu Kecamatan Pancung Soal, (3)Aktivis Sosial \& Asosiasi Serikat Buruh, (4)Tokoh Masyarakat. Teknik pengumpulan data dilakukan melalui teknik wawancara, observasi dan studi atau analisis dokumen.
Uji keabsahan data menggunakan teknik keajegan/ketekunan pengamatan. Kemudian data yang didapatkan akan dianalisis melalui tahap reduksi data, penyajian data dan kemudian penarikan kesimpulan.

\section{HASIL DAN PEMBAHASAN \\ Pengendalian}

Terkait dengan Pengendalian Dinas Lingkungan Hidup dalam hal ini setidaknya mempunyai peran dalam empat hal, yaitu:

1) Melakukan Pengawasan

Terkait dengan melakukan pengawasan Pemerintah Daerah telah mengimplementasikan terhadap dokumen lingkungan yang dimiliki oleh PT.Incasi Raya terhadap bagaimana pengelolaan dan pemantauan lingkungan dengan pengawasan yang dilakukan dua kali dalam setahun. Adapun pengawasan dan anggarannya langsung dari dinas. Bentuk evaluasinya adalah apabila ada perusahaan di atas baku mutu maka akan dilakukan pembinaan. Kendalanya hingga saat ini ialah Dinas Lingkungan Hidup SDM yang telah mengiku diklat Pejabat Pengawas Lingkungan Hidup Daerah.

Pihak perusahaan dalam pengolahan limbah pernah ditegur secara tertulis langsung dari kementerian dan pernah dapat teguran dari kehutanan yaitu mengenai seratus meter dari sungai harus ada hutan lindung, tetapi buktinya tidak ada.

Dari paparan di atas dapat disimpulkan bahwa dalam hal ini, Pemerintah Dinas Lingkungan Hidup mempunyai peran dalam rangka pencegahan pencemaran air air sungai di kecamatan Pancung Soa, Kabupaten Pesisir Selatan.

2) Melakukan Pengujian Kualitas Air

Terkait dengan pengujian kualitas air Pemerintah Dinas Lingkungan Hidup telah melakukan pengujian kualitas air sekali dalam tiga bulan dan dilaporkan setiap enam bulan. Pernah langsung dari kementerian Lingkungan Hidup menguji hasil lab dan menurut tokoh masyarakat ditemui ada masalah dengan kualitas air dan 
berdampak terhadap sepesies hewan air dan aktivitas nelayan terutama 100 meter dari bibir pantai hampir nelayan tidak bisa menangkap ikan karena ikannya banyak mati karena zat limbah cair yang dibuang.

\section{3) Sosialisasi Pengelolaan Lingkungan Hidup \\ Terkait dengan sosialisasi pengelolaan} lingkungan hidup Pemerintah Dinas Lingkungan Hidup terakhir melakukan sosialisasi pada tahun 2018 dengan mengundang narasumber langsung dari kementerian lingkungan hidup dan juga dari Kehutanan propinsi dan pusat. Hadir dari perwakilan dari setiap pelaku usaha, pihak perusahaan, pihak hotel dan rumah sakit. Selain sosialisasi secara formal juga diadakan sosialisasi secara non formal seperti rapat khusus di gedung Bupati mengenai pengelolaan lingkungan hidup.

\section{4) Membuat PERDA}

Terkait dengan regulasi atau peraturan daerah mengenai lingkungan hidup pemerintah Kabupaten Pesisir Selatan memiliki Perbup No 54 Tahun 2017 tentang petunjuk teknis dokumen UKLPL. Adapun evaluasi dari Perbup tersebut ialah setiap izin lingkungan yang dikeluarkan mengacu pada Perbup tersebut. Namun ada beberap jenis usaha yang belum tersentuh oleh perbup ini seperti usaha sarang wallet yang sedang marak-maraknya. Namun menurut salah satu pengurus asosiasi serikat buruh mengatakan bahwa pengawasan dari regulasi tersebut masih lemah.

\section{Pengawasan}

Terkait dengan Pengawasan Dinas Lingkungan Hidup dalam hal ini setidaknya mempunyai empat peran, yaitu:

1) Meminta Keterangan

Terkait dengan meminta keterangan Dinas Lingkungan Hidup meminta keterangan kepada pihak perusahaan sekali dalam enam bulan dan sekurang-kurangnya sekali dalam setahun. Salah satu permasalahannya yaitu mengenai dampak lingkungan yang menjadi pengaduan masyarakat namun tidak ada tindak lanjutnya.

2) Mengambil Sampel

Terkait dengan pengambilan sampel langsung diambil oleh pihak perusahaan dan kemudian hasilnya dilaporkan kepada Dinas Lingkungan Hidup setelah menjadi hasil labor dan bekerjasama dengan LabKes yang sudah terakreditasi karena Dinas belum memiliki Lab yang sudah terakreditasi. Kemudian ketika pengambilan sampel didampingi oleh Tim Labor dari Lingkungan Hidup. Adapun periode pengambilan sampel ialah sekali dalam tiga bulan.

3) Memeriksa Instalasi dan/atau Transportasi

Terkait dengan memeriksa instalasi dan/atau transportasi Pemerinta Dinas Lingkungan Hidup telah melakukan pengawasan terhadap IPAL dan terakhir hasilnya masih memenuhi baku mutu sesuai dengan Permen LH No 68 Tahun 2016. Jika ditemui baku mutunya di atas ambang maka akan dilakukkan pembinaan berupa teknologinya diganti dan pengerukan ulang terhadap komponen-komponen yang ada.

Menurut pengakuan informan yang lain bahwa dulu penggunaan IPAL secara manual dan di tahun 2018 selaku Pemerintahan Nagari Tluk Ampalu merekemondasikan untuk teknologi IPAL. Kemudian mengenai pemeriksaan secara berkala belum ada.

4) Penghentian Pelanggaran yang terjadi

Terkait dengan penghentian jika terjadi pelanggaran Dinas Lingkungan Hidup menyurati pihak yang bersangkutan dan meminta agar mengevaluasi kembali kinerja perusahaan dan setelah itu melakukan pengecekan di lapangan guna mengumpulkan fakta-fakta. Salah satu contohnya ialah teguran agar memperbaiki IPAL dan normalisasi sungai. 


\section{Pemulihan}

Terkait dengan Pemulihan dalam hal ini Dinas Lingkungan Hidup setidaknya memiliki tiga peran, yaitu:

1) Pengehntian Sumber Pencemaran dan Pembersihan Unsur Pencemar

Terkait melakukan penghentian sumber pencemaran secara langsung Dinas Lingkungan Hidup selama ini belum ada, namun Pemda memberikan pembinaan, teguran dan saran. Jadi dalam hal ini Dinas Lingkungan Hidup lebih kepada sifatnya pengawasan berupa teguran dan secara teknis dilaksanakan oleh pihak perusahaan.

\section{2) Pemulihan/Restorasi}

Terkait dengan pemulihan atau restorasi yang dilakukkan oleh Dinas Lingkungan Hidup ialah menyarankan adanya Ruang Terbuka Hijau (RTH) agar tumbuhantumbuhan asli daerah tetap terjaga, namun dalam hal pemeliharaannya masih terabaikan. Kemudian dilaksanakan juga pemulihan batang air atau normalisasi sungai dan salah satu komitmen dari Pihak Perusahaan ialah membuat pintu air di jalur simpang empat perbatasan kecamtan Pancung Soal dengan Kecamatan Lunang. Namun kenyataanya di lapangan normalisasi sungai belum berdampak dengan masih banyaknya eceng gondok yang menganggu stabillitas sungai.

3) Cara lain yang sesuai dengan perkembangan ilmu pengetahuan dan teknologi.

Terkait dengan hal ini Dinas Lingkungan Hidup telah merencanakan penerapan daya dukung beban pencemaran sungai, jadi setiap perusahaan yang membuang limbah ke sungai harus memenuhi daya dukung beban pencemaran. Di samping itu DLH selalu konsisiten untuk normalisasi sungai agar bisa mengalir dengan lancar. Adapun untuk teknologi lebih kepada pihak perusahaan karena dinas focus pada pengawasan.

\section{PENUTUP}

Berdasarkan hasil penelitian dan pembahasan yang telah dilakukan, maka dapat ditarik kesimpulan yakni:

Peran Dinas Lingkungan Hidup dalam pencegahan pencemaran air sungai telah dilakukan secara maksimal dengan tupoksi dan regulasi yang ada meski masih banyak ditemui persoalan di lapangan. Selaku Pemerintah Daerah Dinas Lingkungan Hidup selama ini baru sebatas pengawasan dan sanksi berupa teguran dan pembinaan, namun secara teknis sepenuhnya dilakukan oleh Pihak Perusahaan sebagai pelaku usaha.

Sejauh ini persoalan mengenai dampak lingkungan di kawasan beroperasinya PT.Incasi Raya yang bergerak di bidang perkebunan kelapa sawit masih belum terselesaikan, masih banyak persoalan yang berkaitan dengan dampak lingkungan salah satunya ialah pencemaran air sungai sehingga mengakibatkan terganggunya aktivitas masyarakat terutama yang mencari penghidupan di sungai. Sebagai pelaku usaha PT.Incasi raya harus menseriusi persoalan pencemaran yang terjadi agar konflik bersama masyarakat dapat diselesaikan.

\section{DAFTAR KEPUSTAKAAN}

Hendrawan, Diana. 2010. "Kualitas Air Sungai Dan Situ Di Dki Jakarta." MAKARA of Technology Series 9(1): 13-19.

Ichtiakhiri, T.H, and Sudarmaji. 2015. "Pengelolaan Limbah B3 Dan Keluhan Kesehatan Pekerja Di PT. Inka (Persero) Kota Madiun." Jurnal Kesehatan Lingkungan 8(1): 118-27. http://dx.doi.org/10.20473/jkl.v8i1.201 5.118-127.

Indonesia, Presiden. 2001. "Peraturan Pemerintah Republik Indonesia Nomor 74 Tahun 2001 Tentang Pengelolaan Bahan Berbahaya Dan Beracun." Presiden Indoensia. 
Egi Putra, Adil Mubarak। Peran Pemerintah Daerah dalam Pencegahan Pencemaran Air Sungai Akibat Limbah Pabrik di Kecamatan Pancung Soal Kabupaten Pesisir Selatan

Moleong, LJ. 2006. "Metodologi

Penelitian.” Kualitalif Sasial.

Mubarak, Adil, S Ip, and M Si. "RPSEP58."

Peraturan Pemerintah Republik Indonesia. 1999. "Peraturan Pemerintah Republik Indonesia Tentang Pengelolaan Limbah Bahan Berbahaya Dan Beracun." Government Regulation No. 18 (18): 1-65.

Perda Pesisir Selatan. 2014. "Peraturan Daerah Kabupaten Pesisir Selatan No 5 Tahun 2014." Pemerintah Daerah Pesisir Selatan 2014(June): 1-2. https://repositories.lib.utexas.edu/hand le/2152/39127\%0Ahttps://cris.brighto n.ac.uk/ws/portalfiles/portal/4755978/ Julius+Ojebode\%27s+Thesis.pdf\%0A usir.salford.ac.uk/29369/1/Angela_Dar vill_thesis_esubmission.pdf\%0Ahttps: //dspace.lboro.ac.uk/dspace-jspui/ha.

Syaputri, Martika Dini. 2017. "Peran Dinas Lingkungan Hidup Kota Surabaya Dalam Pengendalian Pencemaran Air Sungai Brantas." Refleksi Hukum: Jurnal Ilmu Hukum 1(2): 131. 